\title{
Surgical correction of pectus excavatum and carinatum
}

\section{S V SINGH}

\author{
From the Regional Cardiothoracic Surgical Unit, North Middlesex Hospital, Edmonton, London
}

ABSTRACT This paper contains an analysis of the long-term results in 85 patients who had pectus excavatum or carinatum deformities repaired at the North Middlesex Hospital betweeng 1951 and 1977. Seventy-seven patients had operations for correction of pectus excavatum and eight for pectus carinatum. A variety of surgical techniques was used. In the excavatum de formities the best results were obtained by the extensive resection of all deformed cartilages, the correction of the sternal deformity by a simple transverse wedge osteotomy, and by stabilising the chest with a stainless steel plate. For pectus carinatum, the involved cartilages were resected? and an osteotomy of the sternum was performed. We preferred in most cases to stabilise the chest wall with a metal strut in this deformity as well. The best cosmetic results were achieveof? by the use of a stainless steel plate passed beneath the sternum and left for not more than sixi months.

Pectus excavatum or carinatum are congenital abnormalities of the anterior chest wall caused by growth disturbance of the costal cartilages. In pectus excavatum the sternum is depressed, maximally just above the xiphisternal junction, with symmetrical or asymmetrical prominence of the ribs on either side, while in pectus carinatum the lower part of the sternum is elevated, pulling the ribs towards it. The causes of these deformities are uncertain. Brodkin ${ }^{1}$ and Chin $^{2}$ believe that pectus excavatum is the result of excessive diaphragmatic traction on the lower sternum while Mullard ${ }^{3}$ considers it to be caused by failure of osteogenesis and chondrogenesis of the anterior chest wall. Mechanical and electrocardiographic changes are uncommon. ${ }^{45}$

\section{Patients and methods}

The present series includes 85 patients who had their deformities repaired by various surgical techniques during the period 1951-77. There were 49 males and 36 females. Seventy-seven patients had operations for correction of pectus excavatum and eight patients for pectus carinatum. We have analysed our findings to determine whether vari-

Address for reprint requests: Dr SV Singh, National Heart Hospital, Westmoreland Street, LondonW1M 8BA. ations in surgical technique have caused any sig $\stackrel{D}{-}$ nificant difference in the long-term results.

\section{Pectus excavatum}

These patients have been divided into three main groups according to the operative technique: group 1 (19 patients), no stabilisation of sternum ${ }^{6} \underset{0}{x}$ group 2A (12 patients), stabilisation of sternum 3 . with Steinmann pin $^{7}$; group 2B (seven patients). stabilisation of sternum with Kirschner wire ${ }^{8}, \frac{3}{3}$ group 3 (39 patients), sternal osteotomy and stabilisation of sternum with stainless steeP plate, ${ }^{9-11}$ costal cartilages resected subperichondrio ally, ${ }^{6}$ and metal strut removed electively after. complete healing of the chest wall preferably be tween four and six months.

A bilateral submammary incision was used in alR cases. The deformed costal cartilages were expose of after splitting the pectoral muscles, and resected subperichondrially. The sternum was mobilise and its position was corrected by a simple trans verse wedge osteotomy.

\section{Results}

No hospital deaths occurred. Table 1 shows the early postoperative complications that developed 
in 15 patients. All the patients have been followed for between two and 15 years. Table 2 shows the results in various groups of patients. There was a total of 10 recurrences in groups 1 and 2. All these patients had a secondary operation, the result of which was excellent in four and good in six.

Of the patients in group 3,36 had an excellent end result and the cosmetic effect in the remaining three was acceptable. There were no recurrences in this group.

Table 1 Postoperative complications in 77 patients who underwent repair of pectus excavatum

\begin{tabular}{ll}
\hline Group & Complications \\
\hline 1 & $\begin{array}{l}\text { Atelectasis 2 } \\
\text { Paradoxical breathing 2 } \\
\text { Pneumothorax 1 } \\
\text { Wound infection 1 }\end{array}$ \\
\hline 19 patients) & $\begin{array}{l}\text { Pneumothorax 1 } \\
\text { Pleural effusion 1 }\end{array}$ \\
\hline 2B 12 patients) & Wound infection 2 \\
(7 patients) & Superficial wound infection 2 \\
\hline W & Wound separation 1 \\
(39 patients) & Pleural effusion 1 \\
\hline
\end{tabular}

Table 2 Results of surgical correction of pectus excavatum in 77 patients

\begin{tabular}{llll}
\hline $\begin{array}{l}\text { Year of } \\
\text { operation }\end{array}$ & Operative technique & $\begin{array}{l}\text { Number } \\
\text { of patients }\end{array}$ & Results \\
\hline $1951-65$ & $\begin{array}{l}\text { Group 1 } \\
\text { (No stabilisation of } \\
\text { sternum) } \\
\text { Group 2A } \\
\text { (Stabilisation with } \\
\text { Steinmann pin) } \\
\begin{array}{l}\text { Group 2B } \\
\text { (Stabilisation with } \\
\text { Kirschner pin) }\end{array}\end{array}$ & 19 & $\begin{array}{l}\text { Excellent-5 } \\
\text { Good-9 } \\
\text { Recurrence-5 } \\
\text { Excellent-4 } \\
\text { Good-5 } \\
\text { Recurrence-3 } \\
\text { Excellent-2 } \\
\text { Good-3 } \\
\text { Recurrence-2 }\end{array}$ \\
\hline $1966-77$ & $\begin{array}{l}\text { Group 3 } \\
\text { (Combined method) }\end{array}$ & 39 & $\begin{array}{l}\text { Excellent-36 } \\
\text { Good-3 } \\
\text { Recurrence-0 }\end{array}$ \\
\hline
\end{tabular}

\section{Pectus carinatum}

The eight patients consisted of five males and three females whose ages ranged from 3 to 18 years. In all patients, the standard operative technique of Ravitch ${ }^{6}$ was used. In three patients a metal strut was used for stabilisation of the chest wall.

\section{Results}

There were no major complications or deaths. There was one pleural effusion which absorbed spontaneously after a few days and two wound infections which resolved in due course. All patients have been followed for between two and 15 years. The result was excellent in the three patients who had the metal stabilisation. Of the remaining five patients the result was good in four. The deformity recurred in the fifth and another operation was required.

\section{Discussion}

The purpose of the operation is cosmetic and psychological. Although there is no age limit for operation we feel that it is best performed during childhood. Therkelsen ${ }^{12}$ and Gibbon ${ }^{13}$ have advised that the operation should be carried out at an earlier age when the thoracic skeleton is softer and easier to correct.

We believe that stabilisation of the sternum in the correct anatomical position by a metal strut yields superior long-term cosmetic results. This technique also gives stability to the sternum and prevents paradoxical motion in the postoperative period. ${ }^{14}$ The operative technique (combined method in group 3 patients) which has been adopted since 1966 at this Centre has produced an excellent result in most cases with no mortality and little morbidity.

The procedure described by Ravitch ${ }^{615}$ for carinatum deformity has produced good results but we would not hesitate to use the metal strut to stabilise the chest even in this deformity.

I have pleasure in acknowledging the invaluable help of Mr R Hurt and Mr M Bates, the Cardiothoracic Surgeons at the North Middlesex Hospital, in the preparation of this paper.

\section{References}

1 Brodkin HA. Congenital anterior chest wall deformities of diaphragmatic origin. Dis Chest 1953; 24:259-77.

2 Chin EF. Surgery of funnel chest and congenital sternal prominence. Br J Surg 1957; 44:360-76.

3 Mullard K. Observations on the aetiology of pectus excavatum and other chest deformities, and a method of recording them. Br J Surg 1967; 54:115-20.

4 Bevegard S. Postural circulatory changes at rest and during exercise in patients with funnel chest, with special reference to factors affecting stroke volume. Acta Med Scand 1958; 171:695-713.

5 Wegmann T, Schaub F. Die klinische Bedeutung der Trichterbrust. Schweiz Med Wochenschr 1953; 41:986-90.

6 Ravitch MM. The operative treatment of pectus excavatum. Ann Surg 1949; 129:429-44. 
7 Griffin EH, Minnis JF Jr. Pectus excavatum: a survey and a suggestion for maintenance and correction. J Thorac Cardiovasc Surg 1957; 33: 625-36.

8 Mayo P, Long GA. Surgical repair of pectus excavatum by pin immobilisation. $J$ Thorac Cardiovasc Surg 1962; 44:53-5.

9 Adkins PC, Gwathmey O. Pectus excavatum: an appraisal of surgical treatment. $J$ Thorac Surg 1958; 36:714-28.

10 Jensen N, Schmidt R, Garamella J. Funnel chest: a new corrective procedure. $J$ Thorac Cardiovasc Surg 1962; 43:731-41.
11 Paltia V, Parkkulainen KV, Sulamaa M, Wallgren GR. Operative technique in funnel chest: experiences in 81 cases. Acta Chir Scand 1959; 116:90-8.

12 Therkelsen F. Funnel chest. Acta Chir Scandis 1951; 102:36-47.

13 Gibbon JH Jr. Surgery of the chest. Philadelphia and London: Saunders. 1962.

14 Le Roux BT. Maintenance of chest wall stability. Thorax 1964; 19:397-405.

15 Ravitch MM. The operative correction of pectus $\omega$ carinatum. Ann Surg 1960; 151:705-7. 